Original Research

\title{
Nursing Lecturers' Transformasional Leadership In Classroom Management At Nursing And Health Faculty Of Muhammadiyah University Of Semarang
}

\section{Tri Hartiti ${ }^{1}$ Ernawati Ernawati ${ }^{1}$}

${ }^{1}$ University of Muhamadiyah Semarang

\begin{tabular}{|c|c|}
\hline Article Info & Abstract \\
\hline $\begin{array}{l}\text { Article History: } \\
\text { Accepted September 30th, } \\
2019 \\
\text { Key words: } \\
\text { Lecturers; Transformational } \\
\text { leadership }\end{array}$ & $\begin{array}{l}\text { A nursing lecturer is an individual responsible for learning process } \\
\text { management of nursing students who are expected to professionally } \\
\text { provide health services (care provider) in the forms of biological, } \\
\text { psychological, social, and spiritual services to individuals, families, and } \\
\text { communities in the future. A nursing lecturer is expected to have } \\
\text { competences as a classroom management leader who gives opportunities } \\
\text { for students to properly actualize their emotions, the one who effectively } \\
\text { utilizes resources, and who does not only focus on the working results } \\
\text { (Cummings et al., } 2010 \text { and Wong, 2012) known as transformational } \\
\text { leadership. Transformational leadership is widely acknowledged as one } \\
\text { leadership model which improves human resources. This research aims to } \\
\text { figure out the lecturers' transformational leadership in classroom } \\
\text { management at Nursing and Health Faculty of Muhammadiyah University } \\
\text { of Semarang. This non experimental (descriptive) research is conducted } \\
\text { with a survey approach on a population of } 24 \text { nursing lecturers fulfilling } \\
\text { inclusion criteria. Result of the reseacrh showed that } 79.2 \% \text { of nursing } \\
\text { lecturers are females with an average of } 42 \text { years old. } 93.9 \% \text { are master } \\
\text { graduates. } 54.2 \% \text { of lecturers have good transformational leadership while } \\
\text { the other } 45.8 \% \text { still have poor transformational leadership. } 70 \% \text { of } \\
\text { lecturers have charismatic competence while the other } 30 \% \text { have less } \\
\text { charismatic competence. } 62.5 \% \text { of lecturers have idealistic persuasive } \\
\text { competence while the other } 37.5 \% \text { have less idealistic persuasive } \\
\text { competence. } 54.2 \% \text { of lecturers have good inspirational motivation } \\
\text { competence while the other } 45.8 \% \text { have less inspirational motivation } \\
\text { competence. Most transformational leadership components in classroom } \\
\text { management are classified into the good category. However, } 45.5 \% \text { of } \\
\text { them tend to be poor. }\end{array}$ \\
\hline
\end{tabular}

\section{INTRODUCTION}

A nurse is an individual who professionally provides health care (care provider), in the forms of biological, psychological, social, and spiritual services to individuals, families, and communities. A nurse is expected to be professional and has both competences of hard and soft skills. Soft skill is one aspect that a nurse should

Corresponding author:

Tri Hartiti

tri.hartiti@unimus.ac.id

South East Asia Nursing Research, Vol 1 No 2, September 2019

ISSN:2685-032X

DOI: https://doi.org/10.26714/seanr.1.2.2019.83-87 
acquire. Soft skills are greatly required to support hard skills known as technical skills that a nurse obtains during his/her educational processes as nursing students. Soft skills include an ability to adapt, to communicate, to work together, to solve problems, as well as to be confident, discipline, and accurate (Hartiti, 2012). It can be concluded that soft skills are greatly required in the real working environment. Thus, an individual's success is not only based on his/her intellectual quotient but also his/her soft skills which result in his/her working achievements.

Agustian (2007) reports the results of a research conducted by Belt (2001), on respondents of Six Sigma magazine stating that the main problems regarding to soft skills include communication by $88 \%$, interpersonal by $72 \%$, and leadership by $56 \%$ while technical and analytical or known as hard skills are only by $18 \%$. In facts, soft skill trainings are more frequently conducted than the hard skill ones in the real working environment due to the working necessities.

Christian (2008), as quoted by Human Capital magazine, estimates that people with high working complexities require high proportion of soft skill trainings than hard skill ones with a comparison of $70 \%$ to $30 \%$ or even $80 \%$ to $20 \%$. Those are conversely applicable to people with low working complexities. For time allocation, Christian provides a general illustration that those deal with $10-15 \%$ working hours per individual per year. It can be concluded that soft skills are greatly required in the real working environment in which an individual may face various problems. Ideal learning or training designs are expected to have more portions on soft skills including leadership, communication, relationship maintenance, and negotiation.

Soft skills have bigger portions to support individual's success in the real working environment. Having sophisticated hard skills without having good personality or soft skills may result in vain (Ismail, 2007). A study on human resource problems in the last decade is conducted by an Emotional Quality Inventory (EQI) institution. Professionals from all over the world are collected as samples. The results show that IQ which is maximally $20 \%$ of the brain capacity contributes only $6 \%$ for an individual's success, than EQ does. In addition, Carnegie Institute of Teknology finds other proofs that from 10,000 successful persons, $15 \%$ of their success are determined by their technical skills, while the other $85 \%$ are dominated by personality or soft skill factors. Edward Wiggam also finds that 400 or $10 \%$ of 4,000 people lost their jobs due to their technical inability. It means that the other $90 \%$ of people are jobless due to their problems on personality (Christian, 2008).

Soft skills have bigger portion in supporting an individual's success in the real working environment. Having sophisticated hard skills without having good personality or soft skills may result in vain (Ismail, 2007). A study on human resource problems in the last decade is conducted by an Emotional Quality Inventory (EQI) institution. Professionals from the whole world are collected as samples. The results show that IQ which is maximally $20 \%$ of the brain capacity contributes only $6 \%$ for an individual's success, than EQ does. In addition, Carnegie Institute of Teknology finds other proofs that from 10,000 successful persons, $15 \%$ of their success are determined by their technical skills, while the other $85 \%$ are dominated by personality or soft skill factors. Edward Wiggam also finds that 400 or $10 \%$ of 4,000 people lost their jobs due to their technical inability. It means that the other $90 \%$ of people are jobless due to their problems on personality (Christian, 2008).

The objective of this research is to describe the nursing lecturer's transformational competences in classroom management at 
faculty of nursing and health of Muhammadiyah University of Semarang.

\section{METHODS}

This non experimental or descriptive research is conducted with a survey approach to figure out the profile of nursing lecturers' transformational competences in classroom management at Faculty of Nursing and Health of Muhammadiyah University of Semarang by using questionnaire as the measuring device. The research samples are the entire lecturers of Nursing Undergraduate Program of Faculty of Nursing and Health of Muhammadiyah University of Semarang fulfilling inclusion criteria with a total of 24 respondents.

\section{RESULTS}

This research has been carried out on 24 lecturers at the University of Muhammadiyah Semarang. The nursing lecturers collected as the research samples, $79.2 \%$ are female. The lecturers' average age is 42 . The youngest one of 31 years old and the oldest one is 52 years old, and $93,9 \%$ of them is master graduate.

Students' perceptions on the nursing lecturers' leadership competences describe on table 1 that $54.2 \%$ of lecturers have good transformational leadership while the other $45.8 \%$ have not. Most lecturers have charismatic competence but not many of them have idealistic persuasive competence.

Based on the results above, the researchers provide a training module for lecturers to improve their transformational leadership methods in classroom, laboratory, or clinical management as outcomes to develop this research. This module consists of handout materials, lesson plans, schedules, and assessments. This module is prepared based on literature studies and is supervised by experts which is then used to improve their transformational leadership for the benefits of nursing students' soft skill improvements. The module is enclosed.

Table 1

The Nursing Lecturers' Transformational Leadership competences

\begin{tabular}{|c|c|c|c|c|}
\hline \multirow{2}{*}{$\begin{array}{c}\text { Nursing Lecturers' } \\
\text { Transformational } \\
\text { Leadership Component }\end{array}$} & \multicolumn{2}{|c|}{ Good } & \multicolumn{2}{|c|}{ Poor } \\
\hline & $\mathrm{f}$ & $\%$ & $\mathrm{f}$ & $\%$ \\
\hline $\begin{array}{l}\text { 1. Charismatic } \\
\text { competence }\end{array}$ & 17 & 70 & 7 & 30 \\
\hline $\begin{array}{l}\text { 2. Idealistic persuasive } \\
\text { competence }\end{array}$ & 9 & 37.5 & 15 & 62.5 \\
\hline $\begin{array}{l}\text { 3. Inspirational } \\
\text { motivation } \\
\text { competence }\end{array}$ & 13 & 54.2 & 11 & 45.8 \\
\hline $\begin{array}{l}\text { 4. Intellectual } \\
\text { stimulation } \\
\text { competence }\end{array}$ & 13 & 54.2 & 11 & 45.8 \\
\hline $\begin{array}{l}\text { 5. Individual } \\
\text { consideration } \\
\text { competence } \\
\end{array}$ & 13 & 54.2 & 11 & 45.8 \\
\hline Overall & 65 & 54.2 & 55 & 55 \\
\hline
\end{tabular}

\section{DISCUSSION}

Transformational leadership is a vision achievement-based leadership. Michael (2001), and Eisenbeiss et al., (2008) state that transformational leadership improves a nurse's empathy, understanding, working motivation, applicable values, and interests on jobs that he/she has already chosen. Failla \& Stichler (2011) and Stina et al (2008) state that transformational leadership improves a nurse's working satisfaction and working environment. The results of a research conducted by Akerjordet \& Severinsson (2008) suggest that transformational leader's emotional quetient and interpersonal competence improve subordinates' knowledge, care, confidence, participation, and communication that a nurse's working satisfaction and patients' satisfaction are also improving. A lecturer's transformational leadership may influence students' competences in improving their soft skills.

A lecturer's charismatic competence enables him/her to provide visions, goals, 
and strategies for students to become professional nurses.

A lecturer's idealistic persuasive competence may become a role model and an example to be followed. It may also encourage students to have positive attitudes on nursing profession, give examples of positive attitudes to develop his/her positive values as a nurse as well as an image of a professional nurse, and have a good interpersonal relationship.

A lecturer's inspirational motivation competence has a meaning to direct students to have values that being a nurse is a professional choice, to give acknowledgement of nursing profession, and to motivate students in completing their assignments based on their nursing profession, to proportionally give students rewards, to prepare a conducive learning environment.

A lecturer's intellectual stimulation competence enables him to lead the class, develop teaching materials, improve teaching methods, and assigning techniques which stimulate creativities.

A lecturer's individual consideration competence enables students to have confidence in pursuing a carrier and self actualization, to readily face competitions as professional nurse, and to be motivated in educational development.

\section{CONCLUSION}

The nursing lecturers have good transformational leadership competencies.

\section{ACKNOWLEDGEMENTS}

We wish to express our appreciation to all lectures' who participated in this study and University of Muhammadiyah Semarang for valuable assistance during data collection.

\section{CONFLICTS OF INTEREST}

Neither of the authors have any conflicts of interests that would bias the findings presented here.

\section{REFERENCES}

1. Ambarwati S.D (2003), Mengelola Perubahan Organisasional: Isu Peran Kepemimpinan Transformasional Dan Organisasi Pembelajaran Dalam Konteks Perubahan Jurnal Siasat Bisnis No. 8 Vol. 2

2. Balke M.J (2006), Nurse Executives: A Grounded Theory Study Of Dynamic CompetenciesDisertasiNursing University of Capela

3. Bass B.M. \& Avolio B.J. (2002). Multifactor Leadership Quesionare Sampler Set (2nd.ed). Redwood City, California : Mind Garden Inc

4. Bass B.M., \& Avolio B.J., Berson Y, Jung.D.I, (2003), Predicting Unit performance by Assesing Transformational and Transactional Leadership. Journal of Applied Psycology, 88(2) 207-218

5. Bessie L.M \& Carol J.H (2006) Leadership Role and Management function in Nursing: theory \& application 6th edition. Lippincott \& Wilkins: New York

6. Eisenbeiss S.A, Knippenberg D.V, Boerner S, (2008), Transformational Leadership and Team Innovation: Integrating Team Climate Principles, Journal of Applied Psychology, Vol. 93, No. 6, 1438-1446 0021-9010/08/\$12.00 DOI: $10.1037 / \mathrm{a} 0012716$

7. Elfindri (2009), Soft skill Panduan bagi Bidan dan Perawat, Badous Media

8. Hartiti (2009), studi diskriptif kepemimpinan transformasional dan soft skill perawat di RS Roemani Semarang

9. Hartiti

(2012),kepemimpinan transformasional dan soft skill perawat di RS Sultan Agung Semarang, Jurnal Managemen 2013

10. Hartiti (2013), efektivitas kepemimpinan transformasional kepala ruang berbasis soft skill terhadap peningkatan softskill perawat pelaksana di RS Roemani Semarang, Jurnal Managemen 2014 
11. Herold D.M \&Fedor D.B, Caldwell, Liu Y, (2009), The Effects of Transformational and Change Leadership on Employees' Commitment to a Change: A Multilevel Study Journal of Applied Psychology Copyright 2008 by the American Psychological Association, Vol. 93, No. 2, 346-357 0021-9010/08/\$12.00 DOI: 10.1037/0021-9010.93.2.346

12. Ismail G (2007), Soft Skill Untuk menjual diri di Dunia Kerja, Berita Universitas Muhammadiyah Yogyakarta edisi Desember

13. Kaihatu T.S dan Wahju A.R (2007), Kepemimpinan Transformasional dan Pengaruhnya Terhadap Kepuasan atas Kualitas Kehidupan Kerja, Komitmen Organisasi, dan Perilaku Ekstra Peran: Studi pada Guru-Guru SMU di Kota Surabaya

14. Kumar S.E, Sreehari, dkk (2011), Communication skills and Soft skills Dorling Kindersley India Pvt Ltd
15. NurrachmatS \&Wahyuddin M(2004), Peran kepemimpinan transformasional, kepemimpinan transaksional, komunikasi internal, dan pengembangan karir terhadap kepuasan kerja di PT. Sumber Bengawan Plasindo Karanganyar

16. O'Brien J. Martin D.R, Heyworth J , Meyer N.R (2008) Negotiating transformational leadership: A key to effective collaboration, Nursing and Health Sciences (2008), 10, 137143

17. Omer T.Y (2005), Leadership Style of Nurse Manager at the Saudi National Hospitals Disertasi Nursing Science University Of George Mason Fairfax Virginia

18. Soegito, A.T (2010), Kepemimpinan Manajemen Berbasis Sekolah, UNNES Press Semarang 